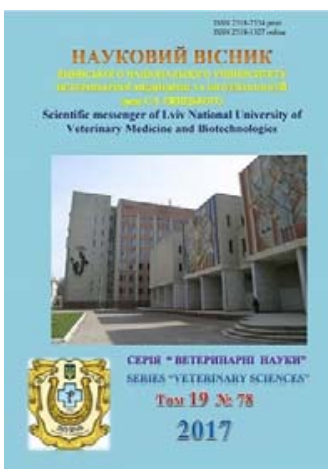

Науковий вісник Львівського національного університету ветеринарної медицини та біотехнологій імені С.З. Гжицького

Scientific Messenger of Lviv National University of Veterinary Medicine and Biotechnologies

doi:10.15421/nvlvet7809

ISSN 2518-7554 print

ISSN 2518-1327 online

$\underline{\text { http://nvlvet.com.ua/ }}$

\title{
Вплив трансплантації культур клітин на перебіг експериментального цукрового діабету у тварин
}

\author{
В.В. Ковпак \\ kovpak8887@gmail.com \\ Національний університет біоресурсів і природокористування Украӥни, \\ вул. Полковника Потехіна, 16, м. Київ, 03041, Украйна
}

\begin{abstract}
3 літературних даних відомо, щзо иукровий діабет I типу виникає через втрату організмом $\beta$-клітин острівиів Лангерганса, які виробляють інсулін, щзо в подальшому призводить до його дефіциту. Лікування цьього типу діабету, навіть на ранніх стадіях, полягає в замінній інсулінотерапії у поєднанні з ретельним контролем рівня глюкози в крові, яке може тривати до кіния життя. Нині триває пошук альтернативних методів лікування даної патології. Одним з таких методів може бути замінна клітинна терапія. Тому метою нашої роботи було дослідити вплив трансплантації культур клітин на перебіг експериментального иукрового діабету.

Досліджено вплив від трансплантації культур клітин кісткового мозку, підилункової залози та жирової тканини на перебіг експериментального иукрового діабету у шурів. Виявлено зниження рівня глюкози у крові дослідних тварин за трансплантації клітинного матеріалу порівняно з контролем. При трансплантачії культури клітин підилункової залози, за експериментального иукрового діабету у щурів, відмічали кращі показники зниження рівня глюкози у крові порівняно з іншими культурами клітин, щуо стало причиною ї̈ подальшого дослідження на котах.

За алогенної трансплантації культури клітин підшлункової залози у котів відмічали різке зниження рівня глюкози в крові дослідних тварин одразу після введення з подальшим поступовим наближенням досліджуваного показника до вихідного стану. На експериментальних моделях відмічено позитивний ефект від трансплантації культур клітин, щуо дає підстави для введення даного методу терапії иукрового діабету в клінічну ветеринарну практику.

Ключові слова: експериментальний иукровий діабет, трансплантачія, культура клітин підилункової залози, культура клітин кісткового мозку, культура клітин жирової тканини.
\end{abstract}

\section{Влияние трансплантации культур клеток на течение экспериментального сахарного диабета у животных}

\author{
В.В. Ковпак \\ kovpak8887@gmail.com
}

Национальный университет биоресурсов и природопользования Украины, ул. Полковника Потехина, 16, Киев, 03041, Украина

\begin{abstract}
С литературных данных известно, что сахарный диабет I типа возникает из-за потери организмом $\beta$-клеток островков Лангерганса, производящих инсулин, что в дальнейшем приводит к его дефициту. Лечение этого типа диабета, даже на ранних стадиях, заключается в заместительной инсулинотерапии в сочетании с тщательным контролем уровня глюкозы в крови, которое может длиться до кониа жизни. Сейчас идет поиск альтернативных методов лечения данной патологии. Одним из таких методов может быть замещающая клеточная терапия. Поэтому целью нашей работы было исследовать влияние трансплантации культур клеток на течение экспериментального сахарного диабета.

Исследовано влияние трансплантации культур клеток костного мозга, поджелудочной железы и жировой ткани на течение экспериментального сахарного диабета у крыс. Выявлено снижение уровня глюкозы в крови опытных животных
\end{abstract}

Kovpak, V.V. (2017). The impact of cell cultures transplantation on the course of experimental diabetes mellitus in animals. Scientific Messenger LNUVMB, 19(78), 41-47. 
при трансплантации клеточного материала по сравнению с контролем. При трансплантации культуры клеток поджелудочной железы, при экспериментальном сахарном диабете у крыс, отмечали лучиие показатели снижения уровня глюкозы в крови по сравнению с другими культурами клеток, что стало причиной дальнейшего исследования на кошках.

При аллогенной трансплантации культуры клеток поджелудочной железы у котов отмечали резкое снижение уровня глюкозы в крови подопытных животных сразу после введения с последуюшим постепенным приближением исследуемого показателя к исходному состоянию.

На экспериментальных моделях отмечено положительный эффект от трансплантации культур клеток, что дает основания для введения данного метода терапии сахарного диабета в клиническую ветеринарную практику.

Ключевые слова: экспериментальный сахарный диабет, трансплантация, культура клеток поджелудочной железы, культура клеток костного мозга, культура клеток жировой ткани.

\title{
The impact of cell cultures transplantation on the course of experimental diabetes mellitus in animals
}

\author{
V.V. Kovpak \\ kovpak8887@gmail.com \\ National University of life and environmental sciences of Ukraine, \\ Polkovnyka Potekhyna Str. 16, Kyiv, 03041, Ukraine
}

As we know from the literature data, type 1 diabetes mellitus occurs due to the loss of $\beta$-cells of island of Langerhans, manufacturing insulin, by the organism, which causes its deficiency. The treatment of this type of diabetes, even at early stages, lies in the substitution therapy together with a careful control of blood glucose which may last for life. It is for this reason that the cellular technologies as an alternative method of treatment of this pathology are growing more and more relevant.

Objective of the study: to study the impact of allogenic transplantation of the cultures of bone marrow, lipid tissue and pancreas cells on the course of experimentally generated diabetes mellitus in animals.

Task: 1. To obtain the cultures of bone marrow, lipid tissue and pancreas cells in rats. 2. To compare the impact of allogenic transplantation of the cultures of bone marrow, lipid tissue and pancreas cells in the course of experimentally generated diabetes mellitus in rats. 3. To study the impact of pancreas cells culture on the course of experimental diabetes mellitus in cats.

The studies were conducted using clinically healthy animals (30 males of white non-pedigree rats with body weight of 200-250 g, aged 4-5 months; 9 white non-pedigree junior rats aged 12 days; 4 mongrel cats aged 15-17 months) and missed fetuses of cats remained after obstetric aid.

Alloxan diabetes was generated by means of single subcutaneous injection of alloxane monohydrate in the dose of $150 \mathrm{mg} / \mathrm{kg}$ in the form of 5\% solution on citrate buffer ( $\mathrm{pH} 4.5$ ) after preliminary 24-hour absolute diet with free access to water.

The cultures of bone marrow and pancreas cells were obtained from the bone marrow of tubular bones and pancreas of puppies aged 12 days correspondingly, lipid tissue - from rats aged 4-5 months. The culture of cats' pancreas cells was obtained from the pancreas of cat fetuses. Cell culture process was carried out according the standard method in $\mathrm{CO}_{2}$ - incubator. Glucose level in blood serum was determined by means of electrochemical analysis.

The results of the study. The authors studied the impact of allogenic transplantation cells culture of bone marrow, lipid tissue and pancreas on the course of experimentally generated diabetes mellitus in rats. The study revealed the decrease of glucose level in the blood of the animals under investigation at cell material transplantation. The most efficient culture for experimental diabetes mellitus therapy is the culture of pancreas cells which has become the cause of its further study in cats.

During allogenic transplantation cells culture of pancreas in cats the authors observed abrupt decrease of glucose level in the blood of the animals under investigation immediately after cell transplantation with the further approximation to the initial state.

The experimental models presented the positive effect of cell culture transplantation providing the grounds for the further implementation of this diabetes mellitus therapy method in the clinical practice.

Key words: experimental diabetes mellitus, transplantation, cell culture of pancreas, cell culture of bone marrow, cell culture of fat tissue.

\section{Вступ}

Цукровий діабет - це група метаболічних захворювань, що характеризуються підвищеним вмістом глюкози в крові (гіперглікемія) в результаті дефектів секреції інсуліну, дії інсуліну або обох факторів. Інсулін - це гормон, що виробляється $\beta$-клітинами підшлункової залози, який необхідний для використання глюкози як джерела енергії, клітинами. При цукровому діабеті 1 типу організм не виробляє інсулін, що призводить до необхідності щоденних його ін'єкцій (Dedov, 2000; Dedov et al., 2001; Zorin, 2005; Shakhbazidi et al., 2006). Проте тривале використання замінної терапії та гіпоглікемічних препаратів може призвести до інсулінорезистентності, а також не запобігає розвиток макро- і мікроваскулярних ускладнень
(Kovalska, 2000; King et al., 2003; Komisarenko et al., 2003).

Тому більш перспективними видаються альтернативні методи лікування цукрового діабету, що полягають у трансплантації клітинних культур, які містять живі $\beta$-клітини та стовбурові клітини (Aliyev et al., 2000; Kovalska, 2000; Thomas et al., 2001; Markov, 2002; Hayek, 2005; Nir and Dor, 2005).

Мета дослідження: дослідити вплив трансплантації алогенних культур клітин кісткового мозку, жирової тканини та підшлункової залози на перебіг експериментально сформованого цукрового діабету у тварин. 


\section{Матеріал і методи досліджень}

В дослідах використовували клінічно здорових тварин (30 самців білих нелінійних щурів масою тіла 200-250 г, віком 4-5 місяців; 9 білих нелінійних щуренят 12-денного віку; 4 безпородних коти віком 1517 місяців) та плоди кошенят, що отримували після надання рододопомоги. Експерименти на тваринах були проведені з дотриманням вимог Закону України «Про захист тварин від жорстокого поводження» (ст. 230 від 2006 року) та Положення про утримання та використання піддослідних тварин в віварії та клініці НАУ, розглянутого та затвердженого ректором НАУ 20.05.2001 p.

Культури клітин кісткового мозку та підшлункової залози отримували 3 кісткового мозку трубчастих кісток та підшлункової залози щуренят віком 12 діб, жирової тканини - від щурів віком 4-5 місяців. Культуру клітин підшлункової залози котів отримували 3 підшлункової залози завмерлих плодів кошенят. Культивування клітин здійснювали за стандартною методикою у $\mathrm{CO}_{2}$-інкубаторі. Для трансплантації використовували культури клітин 2 пасажу. Даний пасаж є оптимальним, оскільки можливо отримати достатню кількість матеріалу, а клітинний склад залишається найбільш гетерогенним та генетично стабільним, що підтверджується дослідженнями, що виконувалися
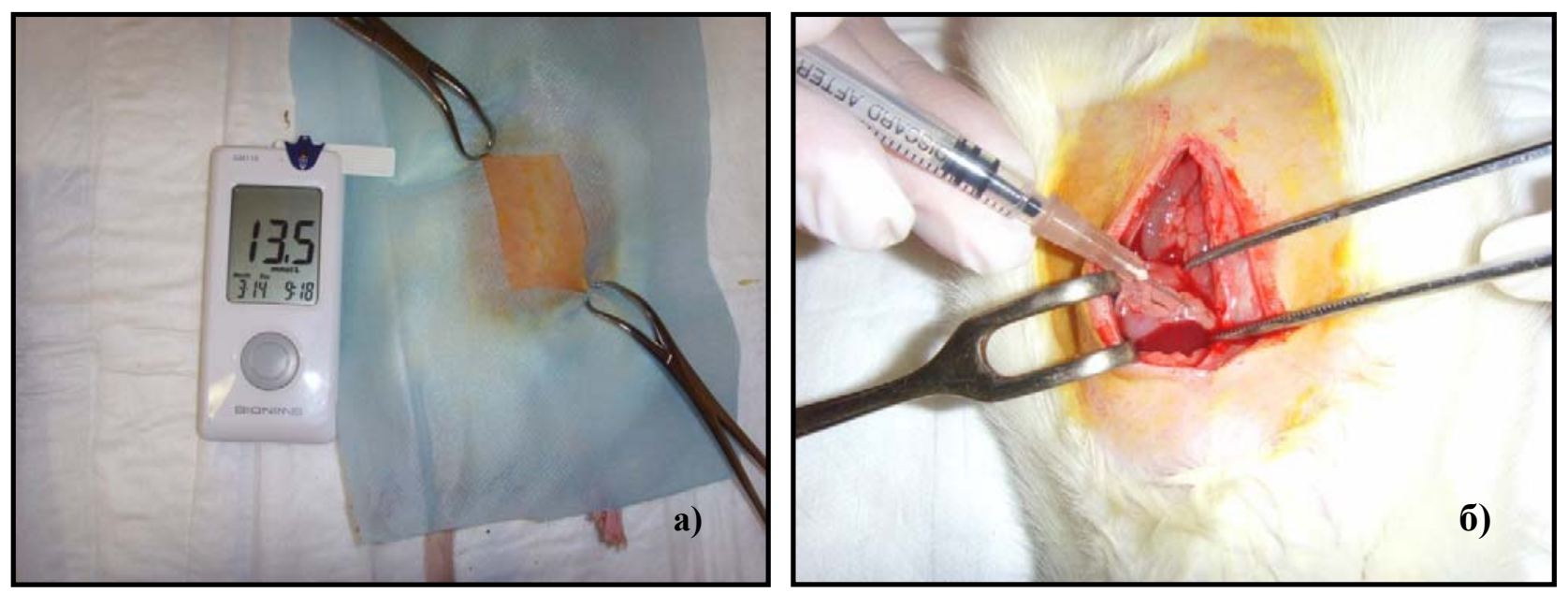

Рис. 1. Трансплантація клітин щурам-реціпіснтам з експериментальним ЦД: а) підготовка операційного поля та вимірювання рівня глюкози; б) введення клітин під капсулу підшлункової залози
Коти були розділені на 4 групи, у кожній з яких проводили трансплантацію ККПЗ у кількості 4 млн під капсулу підшлункової залози (рис. 2). 3 метою дотримань правил біоетики (використання мінімальної кількості тварин) дослід був розтягнутий у часі, так, першому коту клітини культури підшлункової залози вводили на 20 добу експерименту, другому на 30, третьому - на 40 і четвертому - на 50-ту, 3 подальшим визначенням рівня глюкози протягом 50 діб (з інтервалом у 10 діб). Даний метод постановки експерименту дозволив підтвердити відсутність різкого зниження рівня глюкози у крові тварин за відсутності клітинної терапії та прослідкувати оптимальний час трансплантації клітинного матеріалу тваринамреципієнтам. нами раніше (Mazurkevych et al., 2016; Kovpak and Kovpak, 2016; Kovpak, 2016; Kovpak and Kovpak,

Аллоксановий цукровий діабет у тварин формували шляхом одноразового підшкірного введення аллоксану моногідрату в дозі 150 мг/кг у вигляді 5\% розчину на цитратному буфері (pH 4,5) після попередньої 24-годинної голодної дієти при вільному доступі до води.

Щури були розділені на 5 груп по 5 тварин у кожній: I - контрольна (інтактні тварини), II - дослідна, без терапевтичного втручання (відбір крові для аналізу проводили на 20, 34 та 50 доби після введення аллоксану), III - дослідна, тваринам якої на 20 добу після формування ЦД вводили культуру клітин кісткового мозку (КККМ) у кількості 2 млн (відбір крові для аналізу проводили на 34 та 50 доби експерименту), IV - дослідна, тваринам якої на 20 добу після формування ЦД вводили культуру клітин підшлункової залози (ККПЗ) у кількості 2 млн (відбір крові проводили на 34 та 50 доби експерименту), V - дослідна, тваринам якої на 20 добу після формування ЦД вводили культуру клітин жирової тканини (ККЖТ) у кількості 2 млн (відбір крові для аналізу проводили на 34 та 50 доби експерименту).

Трансплантацію клітин здійснювали під капсулу підшлункової залози щурів-реципієнтів (рис.1). 2017; Kovpak and Kovpak, 2017).

Відбір крові для визначення рівня глюкози проводився зранку натщесерце (розрив між годівлею та аналізом складав 12 годин). У щурів відбір крові для аналізу здійснювали 3 кінчика хвоста шляхом його проколу, у котів - з судин вушної раковини. Усі маніпуляції виконувалися після попередньої обробки місця забору крові 5\% розчином йоду. Рівень глюкози в крові визначали шляхом електрохімічного аналізу. Для додаткового контролю рівня глюкози у сироватці крові періодично використовували глюкозооксидазний метод, для якого кров відбирали з головної підшкірної вени у котів та підхвостової - у щурів.

Результати власних досліджень. На 20 добу після формування аллоксанового цукрового діабету в щурів ми виявили збільшення рівня глюкози у крові до 
$13,96 \pm 1,37$ ммоль/л порівняно з вихідним станом 4,70 \pm 0,40 ммоль/л. Отримані результати підтверджуються гістологічними дослідженнями, проведеними нами раніше (Mazurkevych et al., 2015; Mazurkevych et al., 2017), які вказують на руйнування острівців Лангергарса за даного методу формування цукрового діабету. На основі отриманих даних можна стверджувати, що на 20 добу після формування алло-
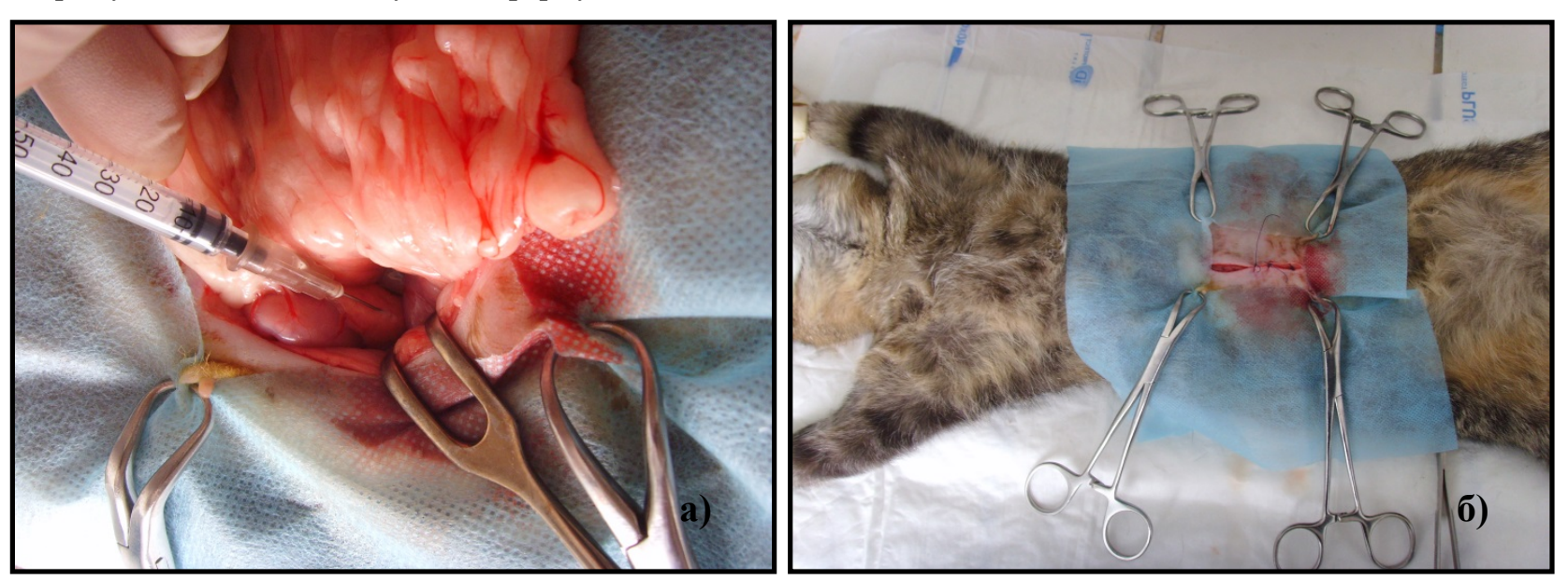

Рис. 2. Трансплантація клітин котам-реціпієнтам з експериментальним ЩД: а) введення клітин під капсулу підшлункової залози; б) завершальний етап операції: накладання швів на шкіру

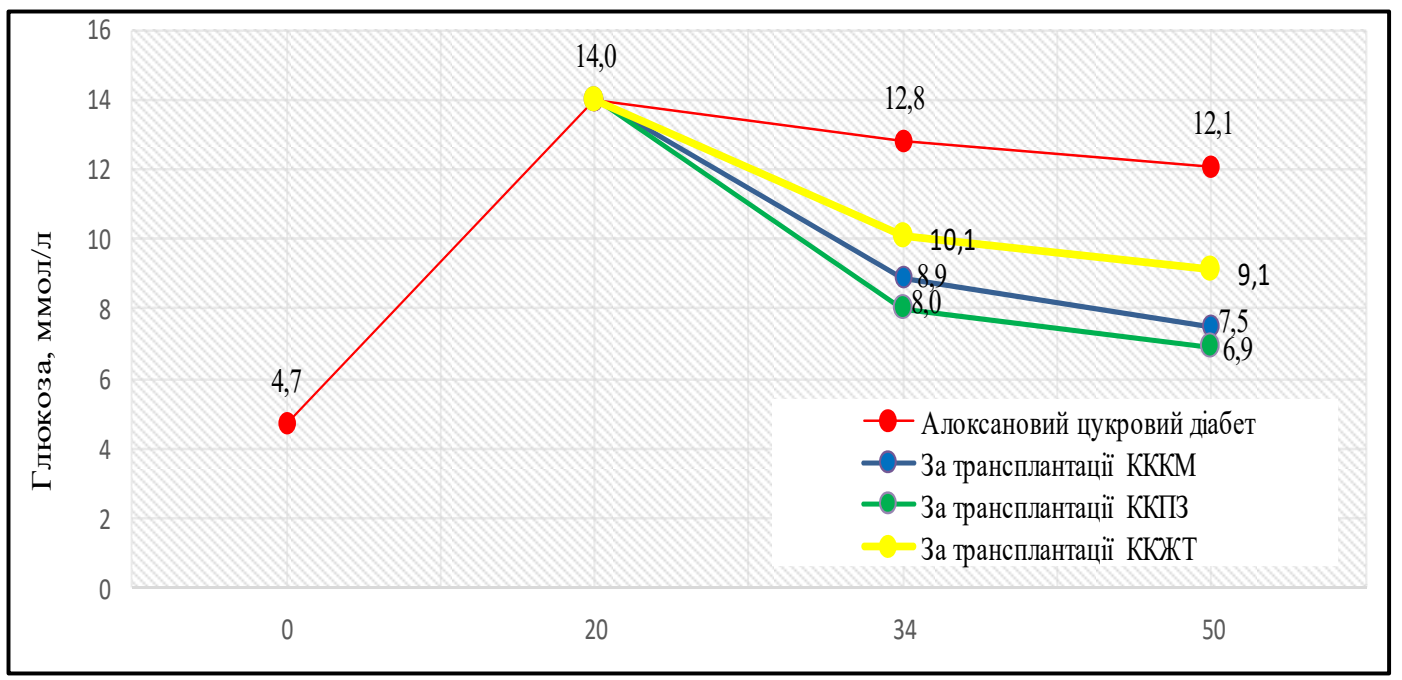

Рис. 3. Тривалість алоксанового цукрового діабету, діб

Наші дослідження показали, що у крові тварин контрольної групи на 34 добу експерименту рівень глюкози становив $12,84 \pm 2,45$ ммоль/л, що на 9\% нижче за показник 20 доби. Це пояснюється тим, що за умови гіперглікемії серед екзокринних ацинарних клітин 3'являються групи інсулін-позитивних клітин (Lipsett and Finegood, 2002).

У тварин дослідних груп (14 доба після введення клітин) рівень глюкози у крові зменшився порівняно 3 контролем за трансплантації КККМ на 30\%; ККПЗ $38 \%$ та ККЖТ $-21 \%$.

Подальші дослідження показали прогресуюче зменшення рівня глюкози у крові дослідних тварин. Так, у щурів контрольної групи він знизився до 12,12 \pm ксанового цукрового діабету окремі тканини дослідних тварин не здатні нормально утилізувати глюкозу 3 крові внаслідок нестачі інсуліну.

На 20 добу після формування цукрового діабету дослідним щурам проводили трансплантацію культур клітин під капсулу підшлункової залози: тваринам III групи - КККМ, IV - ККПЗ, V - ККЖТ (рис. 3). 
збережених $\beta$-клітин підшлункової залози (Federici et al., 2001; Del Zotto et al., 2004), що дозволяє запустити процес самовідновлення острівців Лангерганса (Dor et al., 2004), на що вказує подальше поступове зниження рівня глюкози в крові. Окрім того, за даними групи авторів (Hill et al., 1998; Drozdovych et al., 2003; Galchenko et al., 2004), трансплантовані клітини підшлункової залози частково беруть на себе функції ушкодженого органа, виділяючи біологічно активні речовини як при нормальному функціонуванні, так i при загибелі. Порівнюючи отримані нами та іншими науковцями дані, можна зробити висновок, що основний механізм дії трансплантованої ККПЗ полягає у частковому заміщенні функцій ушкодженої підшлункової залози, це дає можливість відновлення $\beta$-клітин самого організму.

Трансплантація КККМ на фоні експериментального цукрового діабету також мала значний ефект, проте зниження глюкози у крові відбувалося не так різко, як за трансплантації ККПЗ, що свідчить про відмінності впливу даних культур. КККМ виконує трофічну функцію: впливає на регенерацію інших тканин шляхом продукції стимулюючих факторів (цитокінів, факторів росту), які локально супресують імунну систему, інгібують апоптоз і прискорюють васкуляризацію, ділення і диференціювання клітин (Bhatia and Hare, 2005; Moriscot et al., 2005; Caplan and Dennis, 2006).

Трансплантація ККЖТ на фоні експериментального цукрового діабету виявилася найменш ефективною. Спираючись на дослідження, що виконувалися на щурах, де найбільш ефективною культурою клітин за експериментального ЦД виявилася ККПЗ, подальші дослідження на котах були проведені за транспла- нтації ККПЗ котів (рис. 4). У процесі дослідження не відмічали суттєвої залежності часу введення клітин до рівня зниження глюкози у крові. Так, на 10 добу після введення ККПЗ тваринам-реципієнтам у 1-го кота (20 доба досліду) ії кількість знизилася на 28\%, 2-го (30 доба досліду) - на 28\%, 3-го (40 доба досліду) - 29\% та 4-го (50 доба досліду) - 26\% порівняно зі станом до трансплантації.

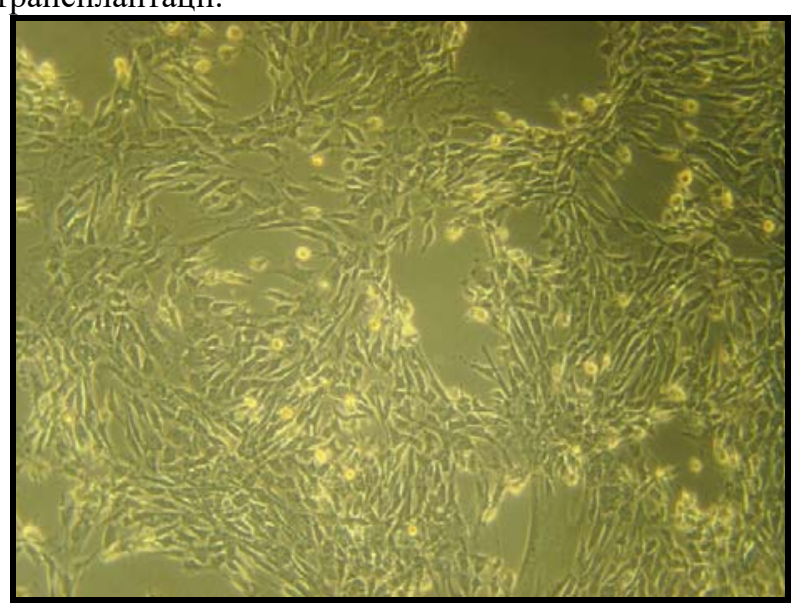

Рис. 4. Мікрофотографія культури клітин підшлункової залози котів in vitro, 2 пасаж. Нативний препарат, зб.×50

Коливання показників можуть бути спричинені розвитком цукрового діабету та переходом його від гострої фази до хронічної (оскільки ЦД є експериментальним).

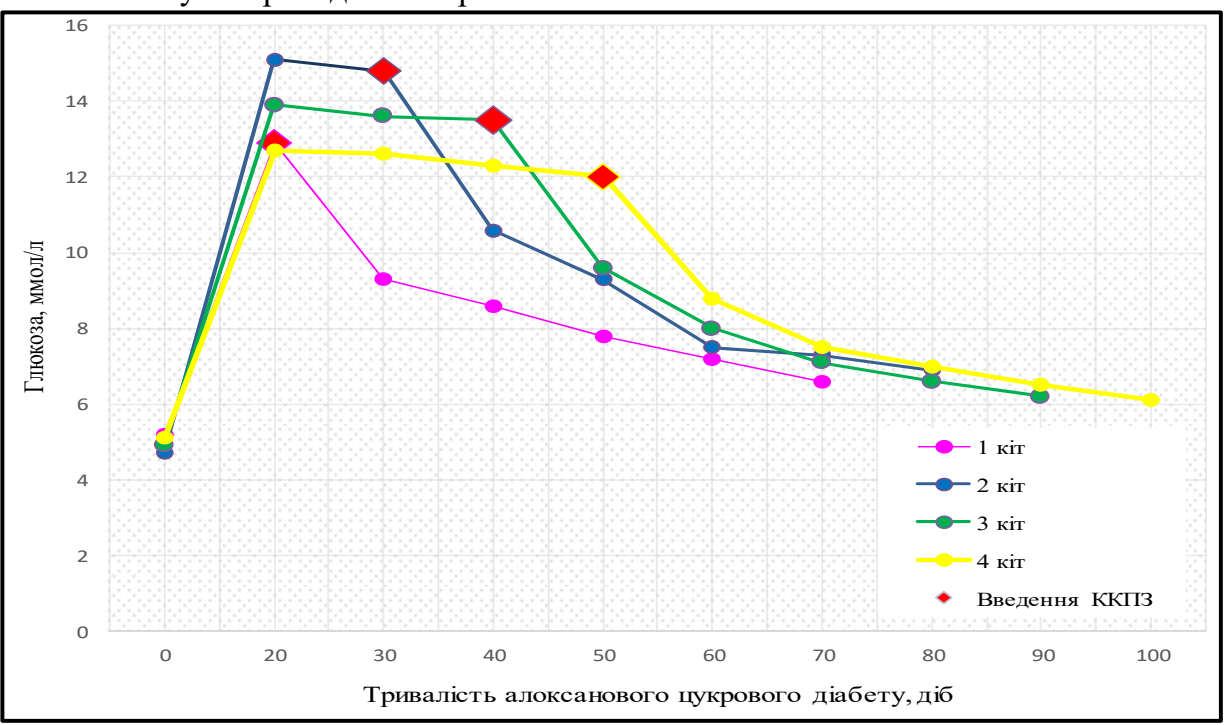

Рис. 5. Рівень глюкози у крові котів за цукрового діабету на фоні трансплантації ККПЗ, $\mathrm{n}=4(\mathrm{M} \pm \mathrm{m})$

Таблиия 1

Рівень глюкози у крові котів за алогенної трансплантації ККПЗ на фоні експериментального ЦД

\begin{tabular}{|c|c|c|c|c|c|c|c|}
\hline \multirow{3}{*}{ Показник } & \multirow{3}{*}{$\begin{array}{c}\text { Вихідний } \\
\text { стан }\end{array}$} & \multicolumn{6}{|c|}{ Аллоксановий цукровий діабет } \\
\hline & & \multirow{2}{*}{$\begin{array}{c}20 \text { доба, конт- } \\
\text { роль }\end{array}$} & \multicolumn{5}{|c|}{ Кількість діб після трансплантації ККПЗ } \\
\hline & & & 10 & 20 & 30 & 40 & 50 \\
\hline Глюкоза ммоль/л & $4,98 \pm 0,15$ & $13,65 \pm 0,99 * *$ & $9,58 \pm 0,61^{*}$ & $8,35 \pm 0,69 *$ & $7,35 \pm 0,35^{* *}$ & $6,90 \pm 0,41 * *$ & $6,45 \pm 0,35 * *$ \\
\hline
\end{tabular}

Примітка: *P $<0,05 ; * * \mathrm{P}<0,01$ (показники 20 доби аллоксанового цукрового діабету порівнювали з вихідним станом; показники $10,20,30,40,50$ доби після трансплантації ККПЗ за ЦД порівнювали 3 показниками 20 доби (контроль) 
На ефективність трансплантації ККПЗ у котів вказувало поступове зниження рівня глюкози у крові дослідних тварин. Так, на 10-ту добу після введення клітин рівень глюкози знизився на 30\%, на 20-ту добу - на 39\%, на 30 -ту - на 46\%, на 40-ву - на 51,50 -ту 53\% порівняно з 20 добою експерименту (табл. 1).

У котів після трансплантації прослідковується закономірність, помічена раніше на щурах: різке зниження глюкози у крові тварин-реципієнтів одразу після введення клітин, що ще раз підтверджує описаний вище вплив культури клітин підшлункової залози.

\section{Висновки}

Трансплантація культури клітин підшлункової залози, культури клітин жирової тканина та культури клітин кісткового мозку за експериментального цукрового діабету сприяє зниженню рівня глюкози у крові тварин-реципієнтів.

Введення культури клітин підшлункової залози сприяє різкому зниженню рівня глюкози у крові одразу після трансплантації 3 подальшим поступовим наближенням до вихідного стану як у щурів, так і у котів.

За трансплантації культури клітин кісткового мозку рівень глюкози у крові тварин реципієнтів знижується поступово.

Трансплантація культури клітин жирової тканини має найнижчий ефект при застосуванні на фоні експериментального цукрового діабету порівняно з культурами клітин кісткового мозку та підшлункової залози.

Перспективи подальших досліджень. На експериментальних моделях відмічено позитивний ефект від трансплантації культур клітин, що дає підстави для введення даного методу терапії цукрового діабету в клінічну практику

\section{Бібліографічні посилання}

Aliyev, M.A., Ismagilov, R.Z., Rysbekov, M.M. (2000). Transplantatsiya kul'tur ostrovkovykh kletok podzheludochnoy zhelezy bol'nym sakharnym diabetom [Transplantation of cultures of islet cells of the pancreas to patients with diabetes mellitus]. Transplantologiya-Transplantology. 1(1), 147-151 (in Russian).

Galchenko, S.Ye., Belochkina, I.V., Mamontov, A.V. (2004). Vliyaniye preparatov iz ksenogennoy podzheludochnoy zhelezy na uroven' glikemii i svobodnoradikal'nyye protsessy u krys s eksperimental'nym sakharnym diabetom [Influence of preparations from xenogeneic pancreas on the level of glycemia and free radical processes in rats with experimental diabetes mellitus]. Meditsinskaya khimiyaMedical Chemistry. 6(4), 63-67 (in Ukrainian).

Dedov, I.I. (2000). Bolezni organov endokrinnoy sistemy [Diseases of the endocrine system]. M.: Meditsina (in Russian).

Dedov, I.I., Shestopalova, M.V., Milen'kaya, T.M. (2001). Sakharnyy diabet: retinopatiya, nefropatiya
[Diabetes mellitus: retinopathy, nephropathy]. M.: Meditsina (in Russian).

Drozdovych, I.I., Turchyn, I.S., Larin, O.S. (2003). Deyaki aspekty diyi ksenotransplantata [Some aspects of xenotransplant]. Transplantologiya - Transplantology. 4(1), 81-83 (in Ukrainian).

Zorin, A.I. (2005). Sakharnyy diabet u sobak i koshek [Diabetes mellitus in dogs and cats]. RVZH MDZH. 2, 44-47 (in Russian).

Kovalska, I.O. (2000). Tsukrovyy diabet ta transplantatsiya [Diabetes mellitus and transplantation]. Transplantologiya - Transplantology. 1(1), 140-142 (in Ukrainian).

Kovpak, V.V., Kovpak, O.S. (2017). Porivnyal'na kharakterystyka henetychnoyi stabil'nosti kul'tur klityn zhyrovoyi tkanyny ta kistkovoho mozku shchuriv na rannikh pasazhakh [Comparative analysis of genetic stability of rat adipose and bone marrow cell cultures on earley passages]. Naukovyy visnyk LNUVMBT imeni S.Z. Gzhytskoho. Seriya: Veterynarni nauky. - Scientific Messenger of LNU of Veterinary Medicine and Biotechnologies. Series: Veterinary science. 19(73), 95-100 (in Ukrainian).

Kovpak, V.V., Kovpak, O.S. (2017). Porivnyal'na kharakterystyka fenotypovykh zmin kul'tur klityn zhyrovoyi tkanyny ta kistkovoho mozku $\mathrm{v}$ protsesi kul'tyvuvannya [Comparative analysis of phenotypic changes of adipose tissue and bone marrow cell cultures in the course of cultivation]. Visnyk Poltavs'koyi derzhavnoyi ahrarnoyi akademiyi - The Bulletin of the Poltava state agrarian academy. 1-2, 113-119 (in Ukrainian).

Kovpak, V.V. (2016). Fenotypovi ta morfolohichni zminy $\mathrm{v}$ kul'turi klityn pidshlunkovoyi zalozy shchuriv pid chas kultyvuvannya [Phenotypic and morphological changes of pancreas cells culture of rats during cultivation]. Visnyk Poltavs'koyi derzhavnoyi ahrarnoyi akademiyi - The Bulletin of the Poltava state agrarian academy. 3(82), 72-77 (in Ukrainian).

Kovpak, V.V., Kovpak, O.S. (2016). Sytohenetychnyy analiz kultury klityn pidshlunkovoyi zalozy shchuriv na rannikh pasazhakh [Cytogenetic analysis of culture of pancreatic cells of rats in early passages]. Klitynna ta orhanna transplantolohiya - Cell and organ transplantology. 4(1), 62-65 (in Ukrainian).

Komisarenko, I.V., Bodnar, P.M., Komisarenko, Y.U. (2003). Endokrynolohiya [Endocrinology.]. K.: Zdorovya - Health (in Ukrainian).

Mazurkevych, A.Y., Kovpak, V.V., Kovpak, O.S., Hudz, N.V. (2017). Morfolohichni zminy v riznykh orhanakh shchuriv za aloksanovoho tsukrovoho diabetu [Morphological changes in different organs of rats for aloxane diabetes mellitus]. Veterynarna biotekhnolohiya - Veterinary biotechnology. 30, 152163 (in Ukrainian).

Mazurkevych, A.Y., Kovpak, V.V., Kharkevych, Y.O. (2015). Morfolohichni zminy u pidshlunkoviy zalozi za aloksanovoho tsukrovoho diabetu u shchuriv [Morphological changes in the pancreas for aloxane diabetes in rats]. Naukovyy visnyk NUBiP Ukrayiny. Seriya Veterynarna medytsyna, yakist' i bezpeka 
produktsiyi tvarynnytstva. - Scientific Bulletin of NUBiP of Ukraine. Series Veterinary medicine, quality and safety of livestock products. 227, 155-159 (in Ukrainian).

Mazurkevych, A.Y., Kovpak, V.V., Kovpak, O.S. (2016). Fenotypovi ta morfolohichni zminy kultury klityn kistkovoho mozku shchuriv $\mathrm{v}$ protsesi yikh kul'tyvuvannya [Phenotypic and morphological changes of bone marrow cells culture of rats during cultivation]. Naukovyy visnyk LNUVMBT imeni S.Z. Gzhytskoho. Seriya: Veterynarni nauky. - Scientific Messenger of LNU of Veterinary Medicine and Biotechnologies. Series: Veterinary science. 18, 2(66), 126-131 (in Ukrainian).

Markov, V.O. (2002). Novi pidkhody u kompleksnomu likuvanni tsukrovoho diabetu [New approaches in the complex treatment of diabetes mellitus]. Odes'k. med. zhurnal. - Odessa. med. Magazine. 2, 60-63 (in Ukrainian).

Shakhbazidi, G., Dunayeva, D.D., Gordeyeva, G.I. (2006) Sakharnyy diabet. Diagnostika, klassifikatsiya, kriterii kompensatsii [Diabetes mellitus. Diagnosis, classification, compensation criteria]. Krymskiy terapevticheskiy zhurnal - Crimean therapeutic journal. 2, 62-66 (in Russian).

Bhatia, R., Hare, J.M. (2005). Mesenchymal stem cells: future source for reparative medicine. Congest. Heart Fail. 11(2), 87-91.

Caplan, A.I., Dennis, J.E. (2006). Mesenchymal stem cells as trophic mediators. J. Cell Biochem. 98(5), 1076-1084.

Del Zotto, H., Borelli, M.I., Flores, L. et al. (2004). Islet neogenesis: an apparent key component of long-term pancreas adaptation to increased insulin demand. J. Endocrin. 183, 321-330.

Dor, Y., Brown J., Martinez, O.I., Melton, D.A. (2004). Adult pancreatic b-cells are formed by self-duplication rather than stem-cell differentiation. Nature. 429, 4146.
Federici, M., Hribal, M., Perego, L. (2001). High glucose causes apoptosis in cultured human pancreatic islets of Langerhans. A potential role for regulation of specific bcl family genes toward an apoptotic cell death program. Diabetes. 50, 1290-1301.

Hayek, A. (2005). Cell replacement in type 1 diabetes mellitus. J. Pediatr. Endocrinol. Metab. 18(1), 11571161.

Hill, D.J., Petrik, J., Arany, E. (1998). Growth factors and the regulation of fetal growth. Diabetes Care. 21(2), B60-B69.

King, A., Andersson, A., Berit, L.S. (2003). The role of capsule composition and biologic responses in the function of transplanted microencapsulated islets of Langerhans. Transplantation. 76(2), 275-279.

Lipsett, M., Finegood, D. (2002). Beta-cell neogenesis during prolonged hyperglycemia in rats. Diabetes. 51, 1834-1841.

Moriscot, C., de Fraipont, F., Richard, M.J. (2005). Human bone marrow mesenchymal stem cells can express insulin and key transcription factors of the endocrine pancreas developmental pathway upon genetic and/or microenvironmental manipulation in vitro. Stem Cells. 23(4), 594-603.

Nir, T., Dor, Y. (2005). How to make pancreatic beta cells - prospects for cell therapy in diabetes? Curr. Opin. Biotechnol. 16(5), 524-529.

Qixin, S., Wang, D., Gregg, A.H. (2004) Long-term islet graft survival in NOD mice by abrogation of recurrent autoimmunity. Diabetes. 53, 2338-2345.

Thomas, J.M., Contreras, J.L., Smyth, C.A. (2001) Successful reversal of streptozotocin-induced diabetes with stable allogeneic islet function in a preclinical model of type 1 diabetes. Diabetes. 50(6), 1227-1236. Received 11.09.2017 Received in revised form 30.09.2017 Accepted 2.10.2017 